\title{
Climate as possible reproductive barrier in Pinus radiata (D. Don) interspecific hybridisation
}

\author{
H. Ham, A.-M. Botha, A. Kanzler, B. du Toit
}

Ham H., Botha A.-M., Kanzler A., du Toit B., 2017. Climate as possible reproductive barrier in Pinus radiata (D. Don) interspecific hybridisation. Ann. For. Res. 60(1):- - .

Abstract. Historically, interspecific hybridisation with Pinus radiata D. Don had limited success. The effect of environmental conditions and position of pollination bags in the tree were investigated as possible hybridisation barriers. The study was conducted in a $P$. radiata seed orchard in the Southern Cape (South Africa). Field data were compared to the climatic conditions at natural and commercial provenances of seven Mesoamerican Pinus species identified as possible hybrid partners. In vitro pollen studies were used to confirm whether interspecific crosses with $P$. radiata might be feasible within predefined climatic parameters. The temperature ranges for both top and northern side of $P$. radiata pine trees in the seed orchard was similar to the natural distribution of $P$. radiata, $P$. elliottii Engelm. and $P$. taeda L. in the USA. Results suggested that pollen of $P$. elliottii and $P$. taeda might be more suited to result in the successful pollination of $P$. radiata than the other Mesoamerican pine species tested in this study. Furthermore, the combination of minimum temperature and precipitation also showed a closer correlation to successful hybridisation with $P$. radiata for both $P$. elliotii and $P$. taeda. However, pollen tube elongation studies did not support these results, suggesting that mean temperature might not be the only determining factor of hybridisation success. Three circadian temperature models that mimic natural conditions were developed for Karatara and Sabie (Tweefontein, Witklip and Spitskop). These models will be tested in future in vitro studies to further evaluate temperature fluctuations between day and night regimes as a possible reproductive barrier limiting hybridisation success between $P$. radiata and other Mesoamerican pine species.

Keywords temperature, dew point, relative humidity, Pinus radiata, pollination

Authors. Hannél Ham (hamh@sun.ac.za), Ben du Toit - Department of Forest and Wood Science, Stellenbosch University, Private Bag X1, Stellenbosch, 7602, South Africa; Anna-Maria Botha - Department of Forest and Wood Science, Stellenbosch University, Private Bag X1, Stellenbosch, 7602, South Africa \& Genetics Department, Stellenbosch University, Private Bag X1, Stellenbosch, 7602, South Africa; Arnulf Kanzler - Department of Forest and Wood Science, Stellenbosch University, Private Bag X1, Stellenbosch, 7602, South Africa \& Sappi Forest Research, P.O. Box 473, Howick 3290, South Africa.

Manuscript received April 27, 2017; revised May 22, 2017; accepted May 25, 2017; online first May _, 2017. 


\section{Introduction}

Pinus is considered the most important commercial forestry genus within the Pinaceae family, consisting of various species and varieties (Critchfield 1975, Gernandt et al. 2005, Plomion et al. 2007). Some pines have developed geographical races that are morphologically and physiologically distinct, limiting broad adaptability and hybridisation potential (Krugman \& Jenkinson 1974). Although interspecific hybridisation can occur naturally in various pines, it is mostly limited to species within a subsection (Plomion et al. 2007) and as the genetic distance between species increases one would expect to see an increase in hybridisation barriers (Ellstrand 2014). Where possible, interspecific hybridisation can be used in pine breeding programmes to increase genetic variation through new combinations that would not happen naturally (Zobel $\&$ Talbert 1984). There have been various interspecific hybridisation successes that address the following breeding objectives: Fusarium circinatum and low levels of frost tolerance $(P$. patula Schiede ex Schlechtendal et Chamisso var. patula $x$ P. tecunumanii Eguiluz et Perry) (Kanzler et al. 2014); Cronartium ribicola tolerance and cold hardiness (P. strobus L. $x$ P. wallichiana Jacks) (Lu \& Derbowka 2012); drought tolerance and productivity (P. elliotti Engelm. $x$ P. taeda L.) (Dungey 2001); hardiness, rapid growth rate and timber quality $(P$. rigida Miller $x$ P. taeda) (Huyn 1976, Barnes $\&$ Mullin 1978); and tree production and pulp properties (P. elliottii $x$ P. caribaea Morelet) (Cappa et al. 2013, Wright et al. 1991, Van der Sijde \& Roelofsen 1986).

Despite the above mentioned examples, interspecific hybridisation successes, especially of wide crosses between taxonomic subsections, are difficult and often result in pollination failure (Dungey et al. 2003, Ellstrand 2014). Environmental conditions, biological barriers (for example pollen availability, flowering times, geographic distribution) and physical (climate, wind) limitations (Bannister 1958, Burdon 1977, Boyer 1981, Greenwood \& Schmidtling 1981, El-Kassaby \& Reynolds 1990, Dickson 1995, Dungey 2001, Major et al. 2005, Alzoti et al. 2010, Gruwez et al. 2014) have to be considered in hybridisation programmes to increase pollination success.

Pine breeding programmes make use of fairly simple equipment and protocols to address the above mentioned pollination constraints. One of the key tools is the pollination bag (micro-fibre with clear window in South Africa) used in controlled pollination to limit contamination from foreign pollen (Bramlett \& O’Gwynn 1981, Nel \& van Staden 2005). During controlled-crosses, the environment inside the pollination bag can create unfavourable climatic (temperature and humidity) conditions which could affect pine pollen germination (McWilliam 1959a, Bester et al. 2000). Various studies in different geographic regions, have tested different pollination bag materials that allows for improved air exchange between the inside and outside of the bag, while still restricting foreign pollen contamination (Ferrand 1988, Sweet et al. 1992, Hagedorn \& Raubenheimer 1996, Hagedorn et al. 1997, Hagedorn 2000, Nel \& van Staden 2005, Neal \& Anderson 2004). However, limited information is available on the micro-climate (inside the pollination bag) compared to the macro-climate (outside the pollination bag) as a possible barrier to hybridisation success.

The objective of this study was to investigate if the environmental conditions (temperature, relative humidity $(\mathrm{RH})$ and dew point (DP)) during isolation of female strobili within pollination bags and their position on the tree (top, middle, north and south) can affect pollination success. The climatic conditions of seed orchards where the pine species under consideration is being grown in South Africa were therefore investigated. Microand macro-climate variables were collected at Karatara (Southern Cape) for three consecutive pollination seasons and complimented with macro-climate data from three seed or- 
chards around Sabie, Mpumalanga Province (Tweefontein, Witklip and Spitskop). This data together with natural provenance climatic data (altitude, precipitation and temperature (maximum, minimum and mean)) were used to assess the possible effects of temperature on pollination success. In vitro pollen tube studies were used to confirm whether interspecific crosses with $P$. radiata (female or male partner) might be feasible within predefined climatic parameters. Although pollination success can be measured with in vitro (controlled laboratory) conditions, pollen germination (viability) and tube elongation (Owens et al. 2005, Owens \& Fernando 2007), it does not completely mimic in vivo (in-field) growth but does give an accurate estimate (Taylor \& Hepler 1997; Fernando et al. 2005). Pollen from the following species was used in the in vitro pollen studies: $P$. radiata D.Don (radiata), $P$. tecunumanii (tecunumanii), $P$. maximinoi Moore (maximinoi), P. oocarpa Schiede ex Schltdl. (oocarpa), P. pringlei Shaw ex Sargent (pringlei), and P. elliottii (elliottii). Reference to tecunumanii throughout the manuscript refers to the low elevation (LE), more tropical populations of the species in Belize (northern Guatemala), Honduras and Nicaragua (Dvorak 1985, Dvorak et al. 2009).

\section{Materials and methods}

\section{Environmental conditions of pollination bags}

The primary study was performed in a radiata pine seed orchard at Karatara (33 $54^{\prime} 0^{\prime}$ ' South, $22^{\circ} 50^{\prime} 0$ " East) owned by MTO Forests. The orchard is situated at $239 \mathrm{~m}$.a.s.l. and receives an annual rainfall of $650 \mathrm{~mm}$, mainly in winter. It differs from many other radiata pine seed production areas as the minimum temperatures never fall below freezing even during the coolest months of the year.

Environmental conditions between the top and middle of tree, as well as north and south facing branches, were investigated during the pollination season (July and August) over three consecutive years. For consistency, one clone (AR 366) and 10 ramets per experiment (year interval) were used. Clusters of female strobili were identified and isolated at the second stage of the six-stage development system as described by Bramlett and O'Gwynn (1981). Micro-fibre pollination bags (green cloth with a clear window) were placed over female cone clusters and tied to the branch (13 July). EL USB 2 data loggers (water resistant) were attached to the inside (micro) and outside (macro) of pollination bags to register changes in micro- and macro-climate. Two data loggers were used per pollination bag and will be referred to as a logger-bag set. Hourly temperature $\left({ }^{\circ} \mathrm{C}\right)$, $\mathrm{RH}(\%)$ and $\mathrm{DP}\left({ }^{\circ} \mathrm{C}\right)$ measurements were logged from time of bagging until six weeks after pollination (total of 50 days). A total of 60 data loggers were used: one logger-bag set (20 data loggers) were placed in the top of each radiata ramet for optimum sunlight exposure, while a further two logger-bag sets (40 data loggers) were placed in the middle of each ramet (20 facing north and 20 south). Other data collected included: the date when data loggers were started, date of bagging, location in the ramet (top, middle, north or south), tree identification code, date of cross pollination, date of de-bagging and date when data loggers were removed.

To determine the effect of temperature and $\mathrm{RH}$ on pollination success, data from the day before pollination, day of pollination and two days after pollination were isolated. During the study period (13 July to 31 August 2012, 2013 and 2014), sunrise was approximately at 07:30 and sunset around 17:30. Therefore, day period was taken as 08:00 to 17:00 and night from 17:01 to 07:59. Comparisons were done by plotting daily averages (Theron 2000, Nel $\&$ van Staden 2005), time of hand pollination and pollen droplet ${ }^{1}$ (emergence after pollina-

${ }^{1}$ The pollination drop (pollen droplet) is defined as an aqueous, protein-rich substance secreted at the micropyle of the ovule during pollination which retracts after 
tion).

A secondary study was performed in three seed orchards (Tweefontein $25^{\circ} 0{ }^{\prime} 38^{\prime \prime}$ South,

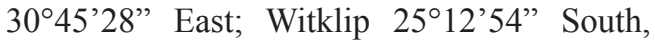
$30^{\circ} 51^{\prime} 41^{\prime \prime}$ East; and Spitskop 25 07'34" South, 3047'08' East) around Sabie (Mpumalanga, South Africa) where oocarpa, tecunumanii, pringlei, maximinoi, elliottii, taeda and patula are planted as potential reciprocal hybrid partners for radiata. Hourly temperature, RH and DP data were collected and analysed over a 50-day period as described earlier (13 July to 31 August 2015). To mimic natural conditions, logger-bag sets were placed randomly in trees (north, south, middle and top). The data were averaged per day and hour, for example 50 (days) temperature readings at 08:00 were averaged to give one value for 08:00. This was done to determine whether reciprocal crosses might be feasible with radiata pollen at these three seed orchards. Only macro-climate data were collected to compare with capturing the pollen grain. It only appears between 02:00 and 04:00 in P. taeda (Williams 2009). the micro- and macro-climate data collected at Karatara. This data, together with the Karatara field data were used to develop three circadian climatic models, simulating temperature, $\mathrm{RH}$ and DP fluctuations, for Sabie (average of Tweefontein, Spitskop and Witklip), Karatara micro- (Kmic) and Karatara macro-climate (Kmac). These circadian models were used in follow-up studies to compare pollen tube germination and elongation of various Pinus species.

\section{Natural climatic conditions versus Karatara}

Provenance data (state, country longitude and latitude) per species were obtained from Camcore (Woodbridge personal communication 2015). Data were filtered to extract provenance data for radiata (Karatara and USA), tecunumanii, oocarpa, maximinoi, pringlei, elliottii, taeda, patula, Tweefontein, Witklip and Spitskop (Figure 1). Although Tweefontein, Witklip and Spitskop are seed orchards and not

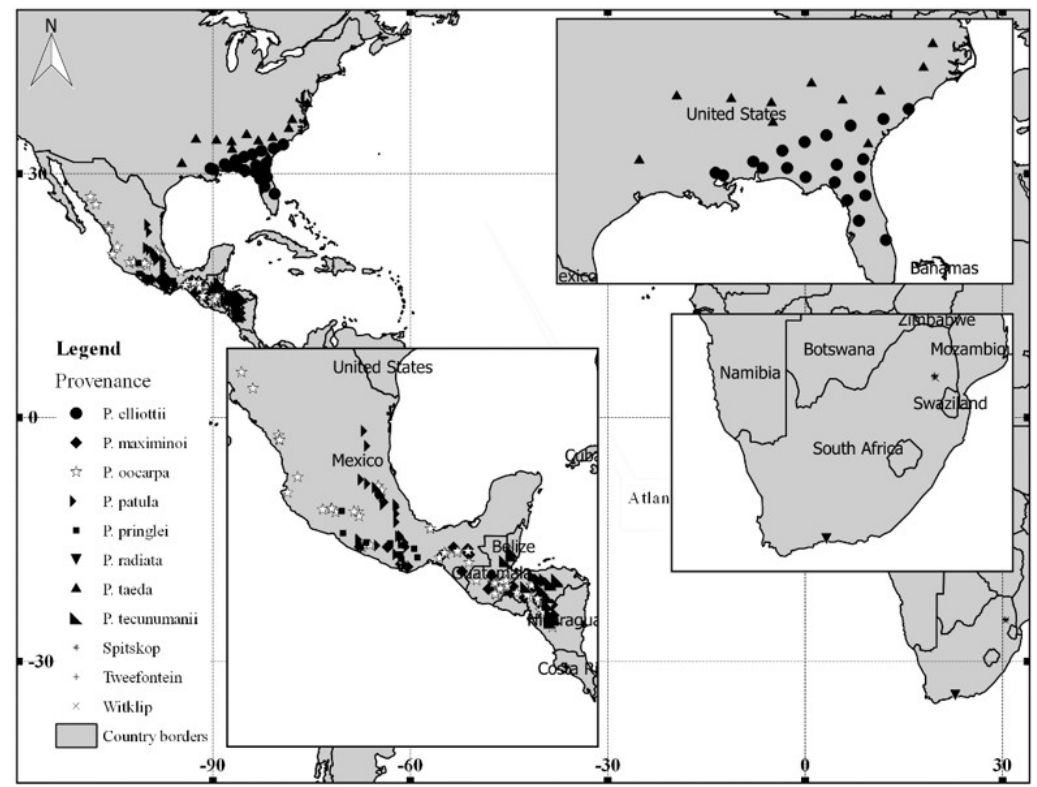

Figure 1 Map of North America and South Africa indicating the natural provenances of P. elliottii, P. maximinoi, P. oocarpa, P. patula, P. pringlei, P. radiata, P. taeda, P. tecunumanii and Sabie (Spitskop, Tweefontein and Witklip). 
species, they are representative of a sample of South African provenances for the seven species and are thus compared to Karatara (South African provenance for radiata).

Bioclim (2016) historical data (interpolations of observed data, representative of 1950 to 2000) for temperatures (maximum, minimum and mean), altitude and precipitation were extracted from map tiles 11, 22, 23, 36, 37 and 46. Data were imported into QGIS 28 Wien as raster images and an overlay was conducted with delimited text layering. Data was extracted for January and February from the natural provenances of the eight species in the Northern Hemisphere, for comparison with the pollination season at Karatara, Tweefontein, Witklip and Spitskop (July and August).

Data were analysed with PROC GLM of SAS/STAT ${ }^{\circledR}$ software (version 9.2, 64 bit, System for Windows 7), and an ANOVA and Shapiro Wilk test $(0.97)$ for normality were accepted on the ground of symmetric distributions. Fisher's Least Significant Difference (LSD) test was conducted to compare species means at $p=0.05$ on the original values of altitude, temperature (maximum, minimum and mean) and precipitation (Shapiro \& Wilk 1965, Ott \& Longnecker 2001, SAS 2013).

A Discriminant Analysis (DA) and Principle Component Analysis (PCA) were performed on the interaction between provenance and species with all five variables and trends were evident (Rencher 2002). Biplots were constructed to distinguish between natural and distinctive groups (DA), while quantitative variables were determined for correlations between multidimensional datasets (PCA) (Kohler \& Luniak 2005, Erasmus et al. 2016).

Statistical analysis was conducted on data sets for altitude, temperatures (maximum, minimum and mean) and precipitation as well as comparison of temperature for the 14 species and commercial provenances (radiata, oocarpa, tecunumanii, maximinoi, patula, elliottii, taeda, pringlei, Karatara, Tweefontein, Witklip, Spitskop, Kmic and Kmac). A completely randomised block experimental design was used with two different time intervals each (months). The sources of variation were partitioned into altitude, temperatures (maximum, minimum and mean), precipitation, species and interaction of provenance and species. The statistical model is given by:

$$
X_{i j}=\mu+Y_{i}+L_{j}+Y L_{i j}+\epsilon_{i j}
$$

altitude, temperature (high, low and mean) and precipitation $\left(X_{i j}\right)$, general mean $(\mu)$, effect of provenance $\left(Y_{i}\right)$, effect of species $\left(L_{j}\right)$, interaction of provenance and species $\left(\mathrm{Y} L_{i j}\right)$ and error $\left(\epsilon_{i j}\right)$.

\section{Pollen germination and tube elongation}

Pollen grain germination and tube elongation were studied in vitro to evaluate if the DA and PCA groupings can be confirmed. Pollen bearing microstrobili (catkins) of seven Pinus species (radiata, maximinoi, oocarpa, tecunumanii, elliottii, taeda and pringlei) were collected during two consecutive pollination seasons (July to October) at various commercial seed orchards throughout South Africa. Pollen was harvested and germinated under controlled laboratory (in vitro) conditions ( Nel $\&$ van Staden 2005). Pollen tube germination, development and growth rate (elongation) were measured for the seven species over a seven-day period (168 hours) at two different temperature treatments. Pollen was evenly dusted onto agar medium in $65 \mathrm{~mm}$ plastic Petri dishes. The $1 \%$ agar solidified medium containing $0.01 \%$ boric acid (Nel \& van Staden 2005). No sucrose was added to the germination medium as different sugars could induce species specific effects on pollen germination, tube development and growth rate (Chira \& Berta 1965).

Two temperature regimes (24 and $32^{\circ} \mathrm{C}$ ), based on previous work of various Pinus species by Jett \& Frampton (1990) and McWilliam (1959b), were followed. Pollen lots were exposed to these temperatures for seven days 
in a growth chamber (Scientific Manufacturing model 1400 LTIS). Petri dishes were covered with aluminium foil, representing enclosed female strobili (seven species at two temperature treatments).

For each temperature treatment, 50 petri dishes per species per day interval (total of 350 per species per treatment) were used. Therefore, during the seven-day period of the experiment, five petri dishes per species were sampled without replacement per 24-hour interval for each of the temperature treatments (total of 25 petri dishes per day per treatment). At each 24-hour sampling point, germination percentage, pollen tube development and pollen tube length and width were assessed. The germination tests were performed to assess pollen viability by counting the number of pollen grains as well as number of germinated pollen grains per microscope field, repeated over five microscope fields (one per petri dish) per pollen sample. A Leica analytical light microscope DM $2500 \mathrm{M}$ at $10 \mathrm{X}$ magnifications was used for the analysis. Pollen grains were considered germinated when the tube lengths were equal to, or exceeding grain diameters. A total of 1500 measurements (Figure 2) were recorded for each temperature treatment per 24-hour interval (Cook \& Stanley 1960). It consisted of 30 pollen grains $\mathrm{x}$

10 pollen tube length or width $\mathrm{x}$ five replications. Pollen tube growth rate was determined by total length or width divided by the amount of hours per 24-hour period since the start of experiment (Williams 2012).

The experiment employed a completely randomised design with a factorial treatment structure: five species and seven time periods (days) with five replications each. An experimental unit (species $\mathrm{x}$ time $\mathrm{x}$ replication) consisted of 350 petri dishes per temperature treatment. An analysis of variance (ANOVA) for each time period was performed using PROC GLM with SAS/STAT ${ }^{\circledR}$ software (version 9.2, 64 bit, System for Windows 7). A Shapiro Wilk test $(0.97)$ for normality was conducted before 268

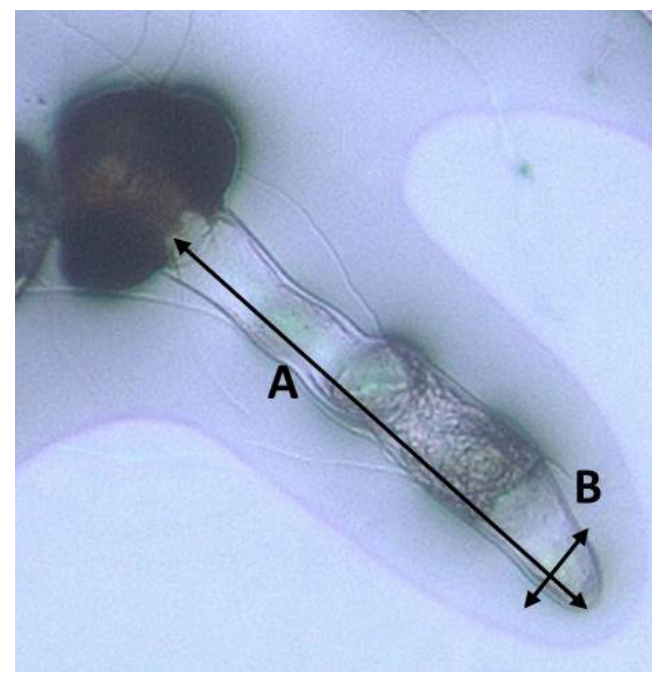

Figure 2 Radiata pollen tube measurement technique at $10 \mathrm{X}$ magnification $(\mathrm{A}$-pollen tube length, $\mathrm{B}$ - pollen tube width).

the results could be assumed reliable.A Fisher's Least Significant Difference (LSD) test with $p=0.05$ was used to compare treatment means (Shapiro \& Wilk 1965, Ott \& Longnecker 2001, SAS 2013). The sources of variation were partitioned into species, replications within temperatures, species and hours, as well as the interactions of temperatures, species and hours. The statistical model is given by:

$$
X_{i j}=\mu+T_{i}+S_{j}+T_{i} S_{j}+H_{k}+T_{i} H_{k}+H_{k} S_{j}+T_{i} S_{j} H_{k}+\epsilon_{i j}
$$

with observed pollen tube size (length and width) and pollen tube growth rate (length and width) $\left(X_{i j}\right)$, general mean $(\mu)$, effect of temperature $\left(T_{i}\right)$; effect of species $\left(S_{j}\right)$, interaction of temperature and species $\left(T_{i} S_{j}\right)$, effect of hours $\left(H_{k}\right)$, interaction of hours and temperature $\left(T_{i} H_{k}\right)$, interaction of hours and species $\left(H_{k} S_{j}\right)$, interaction effect of temperature, species and hours $\left(T_{i} S_{j} H_{k}\right)$ and $\operatorname{error}\left(\epsilon_{i j}\right)$. 


\section{Results}

\section{Environmental conditions inside pollination bags}

Temperature. Data loggers in the top of trees at Karatara indicated larger temperature differences within the micro- than the macro-environment. Temperatures for micro ranged between 8 and $32^{\circ} \mathrm{C}$, while macro ranged between 10 to $22^{\circ} \mathrm{C}$ (Table 1 , Figure 3 ). The micro-temperature was on average $10^{\circ} \mathrm{C}$ higher than macro during the day and on average $1{ }^{\circ} \mathrm{C}$ lower during the night and pollen droplet emergence period. Micro-temperatures increased and decreased more rapidly than the macro-temperature close to sunrise and sun- set, while temperatures peaked around 12:00 (micro) and 15:00 (macro). Comparisons between north and south side of trees, indicated that north was on average $5^{\circ} \mathrm{C}$ warmer during the day and less than $1^{\circ} \mathrm{C}$ cooler than south at night (Figure 4). In the middle of trees, minimum temperatures were on average $4^{\circ} \mathrm{C}$ lower and maximum temperatures were on average $3^{\circ} \mathrm{C}$ cooler compared to the top of the trees. Micro-temperatures peaked between 12:00 (north) and 15:00 (south). For both north and south the micro-temperatures were higher during pollination and lower during pollen droplet emergence period than in the case of the macro-temperatures.

Dew point. There was no clear difference

Table 1 Average temperature $\left({ }^{\circ} \mathrm{C}\right), \mathrm{RH}(\%)$ and dew point $\left({ }^{\circ} \mathrm{C}\right)$ calculated for a 24 -hour period at Karatara and Sabie

\begin{tabular}{|c|c|c|c|c|c|c|c|c|c|c|}
\hline \multirow{2}{*}{\multicolumn{2}{|c|}{ Time (hour) }} & \multicolumn{3}{|c|}{ Temperature $\left({ }^{\circ} \mathrm{C}\right)$} & \multicolumn{3}{|c|}{ Dew point $\left({ }^{\circ} \mathrm{C}\right)$} & \multicolumn{3}{|c|}{ RH (\%) } \\
\hline & & Kmac & Kmic & Sabie & Kmac & Kmic & Sabie & Kmac & Kmic & Sabie \\
\hline \multirow{10}{*}{ Day } & 08:00 & 15 & 19 & 15 & 5 & 10 & 9 & 57 & 56 & 71 \\
\hline & 09:00 & 19 & 24 & 17 & 7 & 14 & 10 & 49 & 48 & 67 \\
\hline & $10: 00$ & 19 & 26 & 19 & 7 & 14 & 10 & 49 & 46 & 61 \\
\hline & $11: 00$ & 21 & 28 & 21 & 7 & 13 & 11 & 46 & 44 & 56 \\
\hline & $12: 00$ & 21 & 28 & 22 & 8 & 14 & 11 & 49 & 46 & 54 \\
\hline & $13: 00$ & 21 & 28 & 23 & 9 & 15 & 11 & 46 & 44 & 52 \\
\hline & $14: 00$ & 21 & 28 & 23 & 8 & 14 & 11 & 50 & 47 & 52 \\
\hline & $15: 00$ & 21 & 27 & 22 & 8 & 14 & 10 & 51 & 48 & 53 \\
\hline & $16: 00$ & 19 & 23 & 21 & 8 & 12 & 10 & 55 & 52 & 54 \\
\hline & $17: 00$ & 17 & 18 & 19 & 8 & 10 & 10 & 63 & 60 & 57 \\
\hline \multirow{14}{*}{ Night } & $18: 00$ & 13 & 12 & 18 & 7 & 7 & 9 & 71 & 70 & 60 \\
\hline & $19: 00$ & 12 & 11 & 17 & 6 & 6 & 9 & 74 & 74 & 62 \\
\hline & 20:00 & 11 & 11 & 16 & 6 & 6 & 9 & 75 & 76 & 63 \\
\hline & $21: 00$ & 11 & 11 & 16 & 5 & 6 & 9 & 73 & 74 & 65 \\
\hline & $22: 00$ & 11 & 10 & 16 & 5 & 6 & 9 & 71 & 73 & 66 \\
\hline & $23: 00$ & 11 & 11 & 15 & 4 & 5 & 9 & 69 & 71 & 67 \\
\hline & 00:00 & 10 & 9 & 15 & 3 & 5 & 9 & 64 & 67 & 68 \\
\hline & 01:00 & 11 & 10 & 15 & 3 & 5 & 9 & 62 & 65 & 69 \\
\hline & 02:00 & 11 & 10 & 14 & 3 & 5 & 9 & 62 & 65 & 70 \\
\hline & 03:00 & 11 & 10 & 14 & 3 & 5 & 8 & 63 & 64 & 71 \\
\hline & 04:00 & 11 & 10 & 14 & 3 & 5 & 8 & 61 & 63 & 71 \\
\hline & 05:00 & 11 & 10 & 14 & 3 & 5 & 8 & 60 & 62 & 72 \\
\hline & 06:00 & 11 & 10 & 14 & 3 & 4 & 8 & 62 & 63 & 72 \\
\hline & 07:00 & 11 & 11 & 14 & 3 & 5 & 8 & 63 & 64 & 72 \\
\hline
\end{tabular}

Note. Abbreviations: Kmac - Karatara macro; Kmic - Karatara micro; Sabie - average of Tweefontein, Spitskop and Witklip 

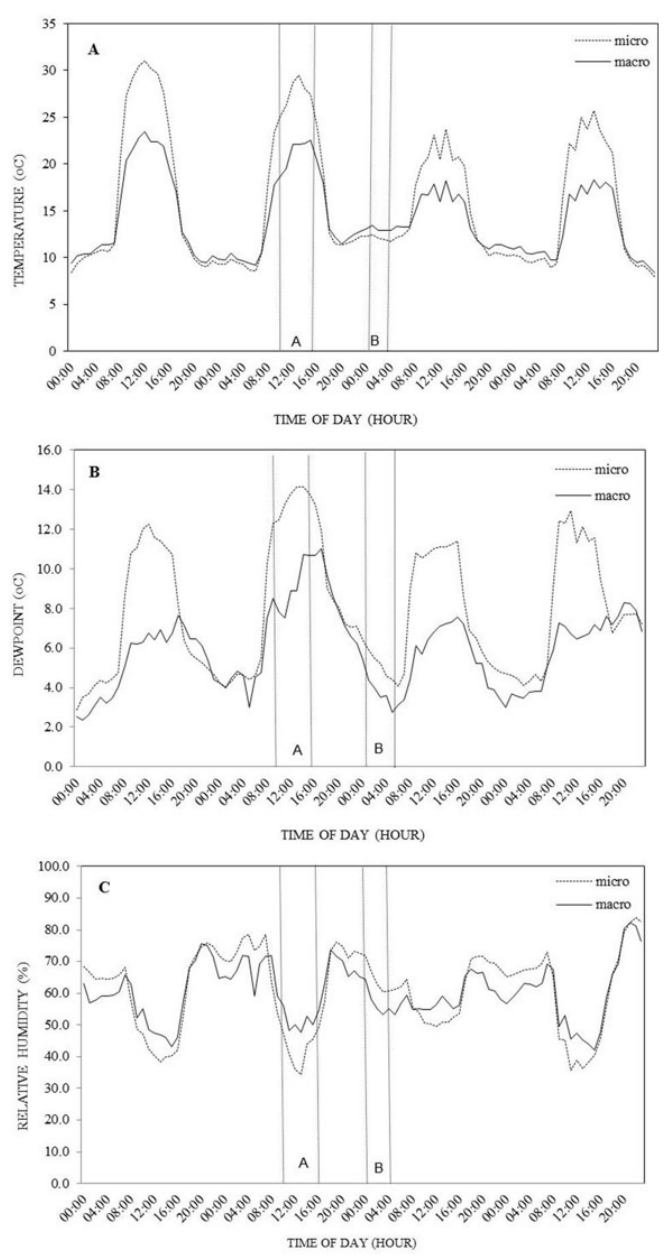

Figure 3 Comparison of average temperature (A), DP (B) and RH (C) for three consecutive pollination seasons at Karatara (A - hand pollination, B - pollen droplet emergence).

in dew point between top and middle of trees (Table 1, Figure 3). Micro-DP ranged from 3 to $14^{\circ} \mathrm{C}$ and macro-DP from 2 to $11^{\circ} \mathrm{C}$. On average, micro-DP was $6^{\circ} \mathrm{C}$ higher during the day and $1{ }^{\circ} \mathrm{C}$ higher at night than macro-DP. There is a sharper increase and decrease in the micro-DP than macro-DP during the day. Comparisons between the north and south indicated that north macro-DP was generally higher than that observed in the south (approximately $4^{\circ} \mathrm{C}$ during the day and $2^{\circ} \mathrm{C}$ at night; Figure 4).
Relative humidity. No clear difference in $\mathrm{RH}$ in the bags between the top and middle of trees were observed (Table 1, Figure 3). Macro- $\mathrm{RH}$ ranged from 40 to $80 \%$ and micro- $\mathrm{RH}$ between 35 to $82 \%$. On average, micro-RH was 7\% higher during the night (pollen droplet emergence) and $14 \%$ lower during the day (pollination period) than in the case with the macro-RH. Comparison between north and south of the tree indicated the north facing micro-RH was $2 \%$ higher during the day (pollination period) and $4 \%$ higher at night than that of the south facing bags (Figure 4). Macro-RH of the north facing area was 5\% lower during the day and $4 \%$ lower at night than that of the south facing bags.

Circadian (24-hour) models. Pollination bags placed in the top northern side of trees had the highest micro-temperature compared to other aspects and locations tested. In general, Kmac (top northern side) was up to $7^{\circ} \mathrm{C}$ cooler than Kmic (top northern side) and only $2^{\circ} \mathrm{C}$ cooler than Sabie during the day (Table 1, Figure 5). However, during the pollination period, $\mathrm{Kmic}$ was up to $7^{\circ} \mathrm{C}$ warmer than that of Sabie and Kmac. During the night, temperatures at Sabie were between 4 and $5^{\circ} \mathrm{C}$ warmer than that of Kmac and Kmic. Furthermore, less pronounced temperature fluctuations were observed at Sabie during the 24-hour temperature cycle than in the case of Kmac and Kmic.

DP values had smaller differences per hour intervals but with the same general pattern as temperature (Table 1, Figure 5). During the pollination period (10:00 and 16:00) Kmac and Sabie differed up to $4^{\circ} \mathrm{C}$, while Kmic was up to $7^{\circ} \mathrm{C}$ warmer than Kmac and Sabie. Night DP of Kmic was warmer than Kmac, with Sabie constantly warmer than both. During the pollen droplet period (02:00 to 04:00) Sabie was considerably warmer $\left(4\right.$ to $\left.5^{\circ} \mathrm{C}\right)$ than $\mathrm{Kmac}$ and Kmic.

In general, RH had smaller differences and fluctuations per hour than temperature and DP (Table 1, Figure 5). During the pollination period (10:00 and 16:00) Kmac and Sabie differed between 2 and $10 \%$, while Kmic did not 


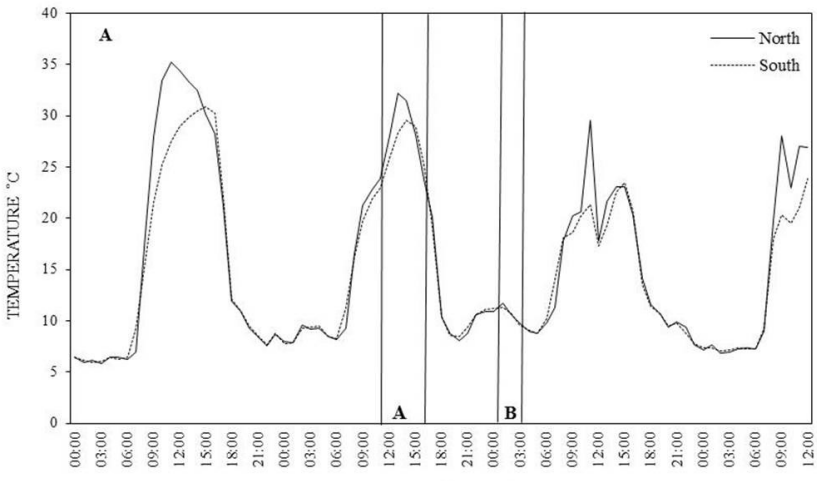

TIME OF DAY (HOURS)

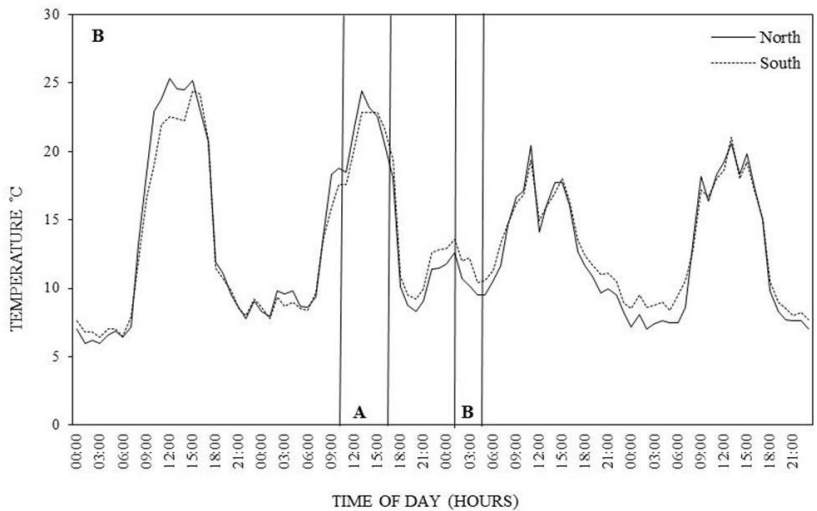

Figure 4 Comparison of the average temperature for the positions of micro top (A) and macro top (B) for three consecutive pollination seasons at Karatara $(\mathrm{A}$ - hand pollination, B pollen droplet emergence)

differ more than $2 \%$ from Kmac, but up to 15 $\%$ from Sabie. Night RH of Kmic and Kmac differed less than $3 \%$, but Sabie was constantly lower during the early evening and higher in the morning (after 00:00). During the pollen droplet formation period (02:00 to 04:00) Kmic and Kmac did not differ more than 3\%, while Sabie was up to $10 \%$ higher than Kmic and Kmac.

\section{Natural growing conditions compared to Karatara}

DA and PCA biplots were constructed to determine whether any of the five variables (altitude, precipitation, maximum, minimum and mean temperature) could be used to distinguish between species. Two distinct quadrants were visible in the DA and PCA biplots (Figure 6, 95\% confidence interval, $\mathrm{F}_{1} \& \mathrm{~F}_{2}=96.8 \%$, $95.4 \%, 98.1 \%, 98.9 \%$ for $\mathrm{A}, \mathrm{B}$, $\mathrm{C}$ and $\mathrm{D}$ respectively). Analysis per pollination month indicated that the second month is significantly cooler but drier than the first $\left(p<0.001, \mathrm{r}^{2}=0.97\right)$. Two separate biplot analyses, consisting of a DA and PCA, were performed: five variables (altitude, precipitation plus three temperature-related variables, Figure $6 \mathrm{~A}$ and $\mathrm{B}$ ); as well as temperature-related variables only (maximum, minimum and mean, Figure 6C and D).

Both analyses grouped the Bioclim (Karatara) and actual data collected during this study (Kmac) together, indicating a strong correlation between historic and actual data. Radiata, elliottii, taeda and Karatara were grouped together in both analyses, indicating good site-species matching. However, the quartet of Karatara, radiata, elliotti and taeda differed significantly from the remaining species for all five variables (Table 2, Figure $6 \mathrm{~A}, \mathrm{~B})$. When only temperature is considered, elliottii and taeda were closely related to Witklip, Tweefontein, Spitskop, radiata and Karatara (Figure 6C, D). However, Kmic was more closely related to maximinoi, tecunumanii and oocarpa than radiata, Karatara and Kmac in the temperature only analysis. Maximinoi and oocarpa grouped together in both analyses (all five variables and temperature only) and differed significantly from the other species, although tecunumanii was closer related. Furthermore, these three species showed a stron- 
Table 2 Comparison of five variables (altitude, precipitation and three temperature-related variables) per species and provenance as a mean for both pollination months

\begin{tabular}{|c|c|c|c|c|c|c|c|c|c|c|c|}
\hline \multirow{2}{*}{ Region } & \multirow{2}{*}{ Species } & \multirow{2}{*}{$n$} & \multirow{2}{*}{\multicolumn{2}{|c|}{$\begin{array}{l}\text { Altitude } \\
\text { (m a.s.1.) }\end{array}$}} & \multicolumn{5}{|c|}{ Temperature $\left({ }^{\circ} \mathrm{C}\right)$} & \multirow{2}{*}{\multicolumn{2}{|c|}{$\begin{array}{l}\text { Precipitation } \\
(\mathrm{mm})\end{array}$}} \\
\hline & & & & & Maximum & Minim & & Mean & & & \\
\hline \multirow{8}{*}{$\begin{array}{l}\text { Meso- } \\
\text { american }\end{array}$} & radiata & 6 & 59 & E & $16 \pm 1^{\mathrm{FG}}$ & $5 \pm 1$ & EFG & $10 \pm 1$ & EF & $84 \pm 49$ & $\mathrm{AB}$ \\
\hline & tecunumanii & 38 & 927 & D & $25 \pm 2^{A}$ & $15 \pm 2$ & A & $20 \pm 2$ & A & $59 \pm 39$ & $\mathrm{BC}$ \\
\hline & oocarpa & 136 & 1222 & D & $25 \pm 3^{\mathrm{AB}}$ & $12 \pm 3$ & $\mathrm{AB}$ & $19 \pm 3$ & $\mathrm{AB}$ & $26 \pm 20$ & D \\
\hline & maximinoi & 52 & 1308 & $\mathrm{CD}$ & $25 \pm 3 \mathrm{AB}$ & $12 \pm 2$ & $\mathrm{AB}$ & $18 \pm 2$ & $\mathrm{AB}$ & $36 \pm 29$ & CD \\
\hline & elliottii & 40 & 49 & E & $18 \pm 3 \mathrm{EFG}$ & $5 \pm 2$ & FG & $11 \pm 2$ & DEF & $112 \pm 23$ & A \\
\hline & taeda & 40 & 80 & E & $15 \pm 4^{\mathrm{G}}$ & $2 \pm 3$ & G & $8 \pm 3$ & F & $111 \pm 20$ & A \\
\hline & pringlei & 22 & 2090 & $\mathrm{AB}$ & $24 \pm 2 \mathrm{ABC}$ & $8 \pm 3$ & $\mathrm{DE}$ & $16 \pm 2$ & $\mathrm{BC}$ & $14 \pm 8$ & $\mathrm{D}$ \\
\hline & patula & 56 & 2371 & A & $20 \pm 3^{\mathrm{DE}}$ & $5 \pm 3$ & EF & $12 \pm 3$ & $\mathrm{DE}$ & $23 \pm 11$ & D \\
\hline \multirow{6}{*}{ RSA* } & Karatara & 12 & 260 & $\mathrm{E}$ & $19 \pm 0$ DEF & $7 \pm 0$ & DEF & $13 \pm 0$ & $\mathrm{CDE}$ & $65 \pm 9$ & BC \\
\hline & Kmac & 2 & 239 & E & $22 \pm 0$ BCD & $8 \pm 0$ & $\mathrm{CD}$ & $12 \pm 2$ & $\mathrm{DE}$ & $65 \pm 11$ & в \\
\hline & Kmic & 2 & 239 & E & $26 \pm 0^{\mathrm{A}}$ & $12 \pm 1$ & $\mathrm{BC}$ & $19 \pm 2$ & $\mathrm{AB}$ & $65 \pm 11$ & в \\
\hline & Witklip & 10 & 1152 & D & $21 \pm 1^{C D}$ & $7 \pm 1$ & DEF & $14 \pm 1$ & $\mathrm{CD}$ & $15 \pm 1$ & D \\
\hline & Spitskop & 10 & 1156 & $\mathrm{D}$ & $21 \pm 1^{\mathrm{CD}}$ & $6 \pm 1$ & DEF & $14 \pm 1$ & $\mathrm{CD}$ & $13 \pm 2$ & D \\
\hline & Tweefontein & 10 & 1712 & $\mathrm{BC}$ & $19 \pm 1^{\mathrm{DEF}}$ & $5 \pm 1$ & EFG & $12 \pm 1$ & $\mathrm{DE}$ & $13 \pm 1$ & D \\
\hline \multicolumn{3}{|l|}{$r^{2}$} & 0.91 & & 0.99 & 0.99 & & 0.99 & & 0.97 & \\
\hline \multicolumn{3}{|l|}{$p<$} & 0.001 & & 0.001 & 0.001 & & 0.001 & & 0.001 & \\
\hline
\end{tabular}

Note. Abbreviations: $n=$ number of provenances, Kmac - Karatara macro; Kmic - Karatara micro. Within a column, means with the same letter are not significantly different *Republic of South Africa

ger correlation with temperature than altitude and precipitation. Patula and pringlei grouped together and showed a closer correlation to Tweefontein, Witklip and Spitskop in both analysis (five variables and temperature only), indicating good site-species matching. In general, Karatara, radiata, elliottii and taeda had a stronger correlation with precipitation and minimum temperature than the other species.

\section{Pollen germination and pollen tube elonga- tion}

Maximinoi and pringlei yielded low germination percentages at both 32 and $24^{\circ} \mathrm{C}$ and were omitted from analysis. Pollen germination differed between species and temperature regimes. Radiata, elliottii and taeda germinated from day 1 onwards at both temperature regimes, while oocarpa and tecunumanii germinated on day 2 at $24^{\circ} \mathrm{C}$ and day 1 at $32^{\circ} \mathrm{C}$.

At $32^{\circ} \mathrm{C}$ (Table 3 ) two groups were evident for pollen tube length and growth rate length as radiata, tecunumanii and oocarpa differed significantly from elliottii and taeda. Radiata and tecunumanii differed significantly from one another and the other species for pollen tube width and growth rate width. No distinct groups were obtained at $24^{\circ} \mathrm{C}$. In general, radiata and tecunumanii differed significantly for pollen tube width and growth rate width, but not for pollen tube length and growth rate length, while germination tempos differed between species. These groupings did not correlate with the DA and PCA results.

\section{Discussion}

Interspecific crosses with radiata have had limited success to date at the Karatara seed orchard in Sedgefield, South Africa. During a typical radiata pollination season at Karatara, pollination bags are placed randomly in the 
Table 3 Average pollen tube length $(\mu \mathrm{m})$, width $(\mu \mathrm{m})$ and growth rate $(\mu \mathrm{m} / \mathrm{h})$ for five pine species after the

\begin{tabular}{|c|c|c|c|c|c|c|c|c|}
\hline \multirow{3}{*}{$\begin{array}{l}\text { Species } \\
\text { radiata }\end{array}$} & \multicolumn{4}{|l|}{$32^{\circ} \mathrm{C}$} & \multicolumn{4}{|c|}{$24^{\circ} \mathrm{C}$} \\
\hline & \multicolumn{2}{|c|}{ Length } & \multicolumn{2}{|c|}{ Growth rate } & \multicolumn{2}{|c|}{ Length } & \multicolumn{2}{|c|}{ Growth rate } \\
\hline & 170 & $\mathrm{AB}$ & 1.00 & $\mathrm{AB}$ & 132 & A & 0.83 & A \\
\hline tecunumanii & 189 & A & 1.10 & $\mathrm{AB}$ & 123 & $\mathrm{AB}$ & 0.71 & $\mathrm{AB}$ \\
\hline oocarpa & 153 & в & 0.90 & в & 112 & $\mathrm{AB}$ & 0.72 & $\mathrm{AB}$ \\
\hline elliottii & 125 & C & 0.73 & C & 106 & c & 0.62 & в \\
\hline \multirow[t]{2}{*}{ taeda } & 129 & C & 0.75 & C & 123 & $\mathrm{AB}$ & 0.73 & $\mathrm{AB}$ \\
\hline & \multicolumn{2}{|c|}{ Width } & \multicolumn{2}{|c|}{ Growth rate } & \multicolumn{2}{|c|}{ Width } & \multicolumn{2}{|c|}{ Growth rate } \\
\hline radiata & 22 & A & 0.13 & A & 18 & $\mathrm{AB}$ & 0.11 & $\mathrm{AB}$ \\
\hline tecunumanii & 19 & в & 0.11 & в & 14 & C & 0.08 & c \\
\hline oocarpa & 16 & $\mathrm{CD}$ & 0.09 & $\mathrm{CD}$ & 16 & $\mathrm{BC}$ & 0.09 & $\mathrm{BC}$ \\
\hline elliottii & 14 & $\mathrm{D}$ & 0.08 & C & 14 & C & 0.08 & C \\
\hline taeda & 16 & c & 0.09 & $\mathrm{CD}$ & 19 & A & 0.11 & $\mathrm{AB}$ \\
\hline
\end{tabular}

Note. Within columns, means with the same letter are not significantly different.

trees and cover conelets for up to six weeks after pollination to improve pollination success. Even though care is taken with pollen management (collection, drying and storage), bagging of flowers, hand pollinations and monitoring of conelets, crossability remained low for interspecific crosses with tecunumanii and oocarpa. Therefore, this study investigated whether climate (temperature, $\mathrm{RH}$ and DP) and position on tree (top and middle; north and south) are possible reproductive barriers limiting said success.

In this study, it was found that pollination bags placed in the top northern side of trees received more direct sunlight for a longer time period (higher temperature inside pollination bags). Previous studies (McWilliam 1959a, Nel \& van Staden 2005) indicated that the maximum temperature difference between the micro- and macro-environment could be as much as $13^{\circ} \mathrm{C}$, while only a $7^{\circ} \mathrm{C}$ difference (20 to $27^{\circ} \mathrm{C}$ ) was observed in this study. Placement of pollination bags in the top northern side of the trees increased daytime temperatures during the pollination period to comparable levels with Sabie where it is known that maximinoi, oocarpa, tecunumanii, pringlei, patula, elliottii and taeda produce seed. How- ever, night time temperatures, when the pollen droplet emerges, inside these pollination bags were substantially lower than at Sabie. Furthermore, the fluctuations between day and night temperatures were also more severe at Karatara than Sabie. An occasional negative DP measured during this study at Karatara indicated that frost was more probable at Karatara than the natural provenances of maximinoi, tecunumanii, oocarpa, patula and pringlei. This supports the argument that the impact of the fluctuations between maximum and minimum temperatures in a 24-hour cycle (circadian model) on pollination success needs to be investigated further.

Limited information is available on the effect of RH and DP on pollination success. When pollen is introduced into pollination bags with a high RH, it will become water saturated and be less effective which can potentially result in lower germination. The risk of diseases or bacterial contamination might also increase (Nel \& van Staden 2005). Whereas, a lower $\mathrm{RH}$ might affect the pollen droplet emergence negatively as the moisture difference between the inside and outside of the microstrobili may be too severe (Sweet et al. 1992). However, if the air is too dry, it might induce abortions 


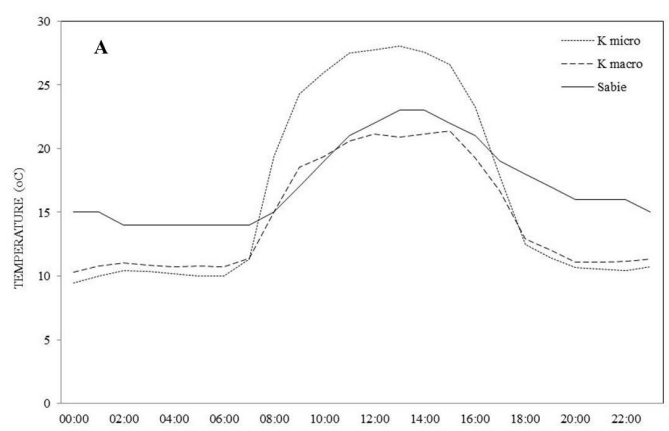

TIME OF DAY (HOUR)
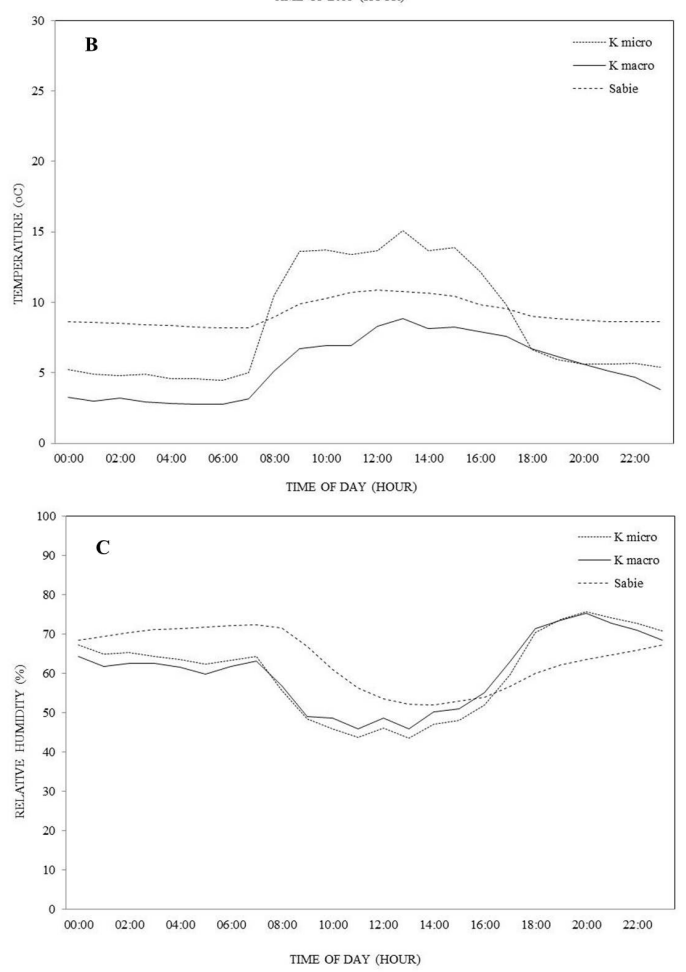

Figure 5 Comparison of the three circadian climatic models for Karatara micro, Karatara macro and Sabie (average of Tweefontein, Spitkskop and Witklip) for temperature (A), DP (B) and RH (C).

of microstrobili due to dehydration (Nel 2002, Neal \& Anderson 2004, Gruwez et al. 2014). McWilliam (1959b) also observed that extreme temperatures and limited air movement might lead to limited pollen germination success. Therefore, the balance between $\mathrm{RH}$ and temperature seems to be delicate and might have a bigger impact on pollination success than previously considered.

Radiata grows well in the southern Cape and is evidently well adapted to the average macro-climatic conditions observed during this study as confirmed by the DA biplots (Figure 6A). Maximinoi, patula, pringlei, oocarpa, tecunumanii, elliottii and taeda are well adapted to the Sabie region (Tweefontein, Witklip and Spitskop) as confirmed by the DA biplots. Based on the PCA biplots, these species (excluding elliottii and taeda) are however not genetically closely related to radiata (Dvorak et al. 2000), nor correlate well to the southern Cape (Karatara) in terms of the climate variables tested (Figure 6B). This could be one potential reason why interspecific hybridisation between radiata and these species have had limited success to date.

DA biplot (Figure 6A) indicated a strong correlation between radiata, Karatara and the pollination bags placed in the northern top of trees at Karatara (Kmic and Kmac). Therefore, the data collected at Karatara not only correlates well with the Bioclim historic data, but also indicated that elliottii and taeda can be planted at Karatara although the duo are not genetic closely related to radiata (Dvorak et al. 2000). The three seed orchards (Tweefontein, Spitskop and Witklip) representing Sabie in this study, grouped together and were closer correlated with tecunumanii, oocarpa, maximinoi, pringlei and patula than with radiata, elliottii and taeda. Although altitude is influenced by latitude, the combination of altitude and temperature does have an impact on the geographic distribution of a species. For example, patula is more closely related to the vector of altitude but less to precipitation than radiata (Figure $6 \mathrm{~B}$ and Table 2). This is in agreement with Poynton (1979) that radiata does not perform as well in the Sabie region as patula due to the altitude, occurrence of frost and diseases. Also, the length of vectors altitude and precipitation are longer than temperature, indicating that the species in this study 

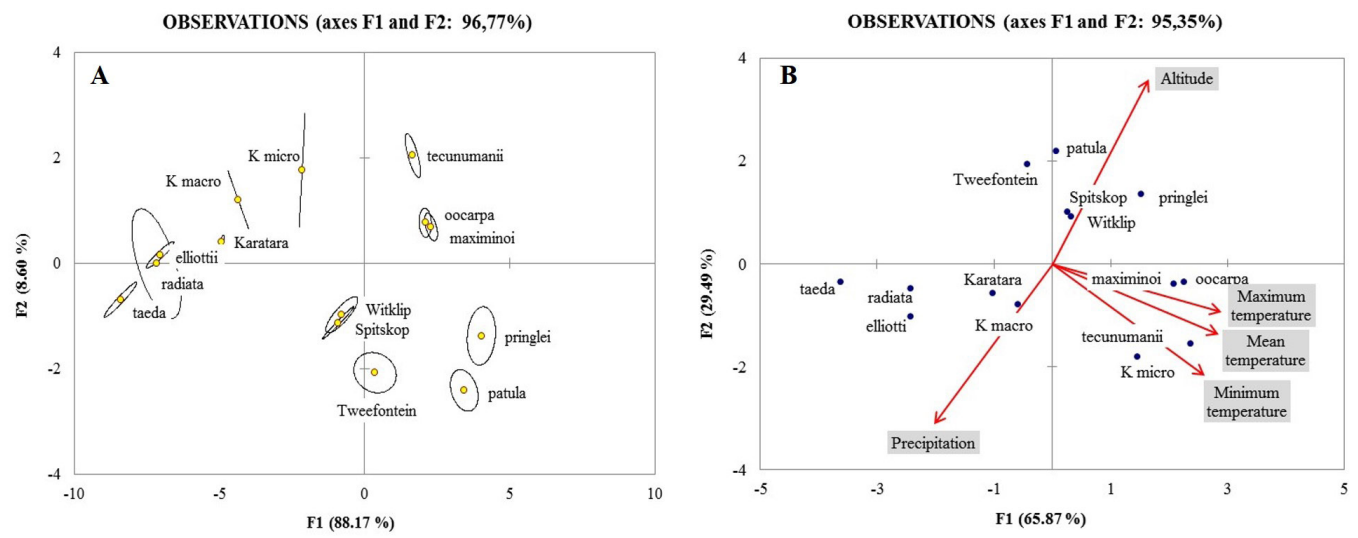

OBSERVATIONS (axes F1 and F2: 98,14\%)

OBSERVATIONS (axes F1 and F2: 98,91\%)
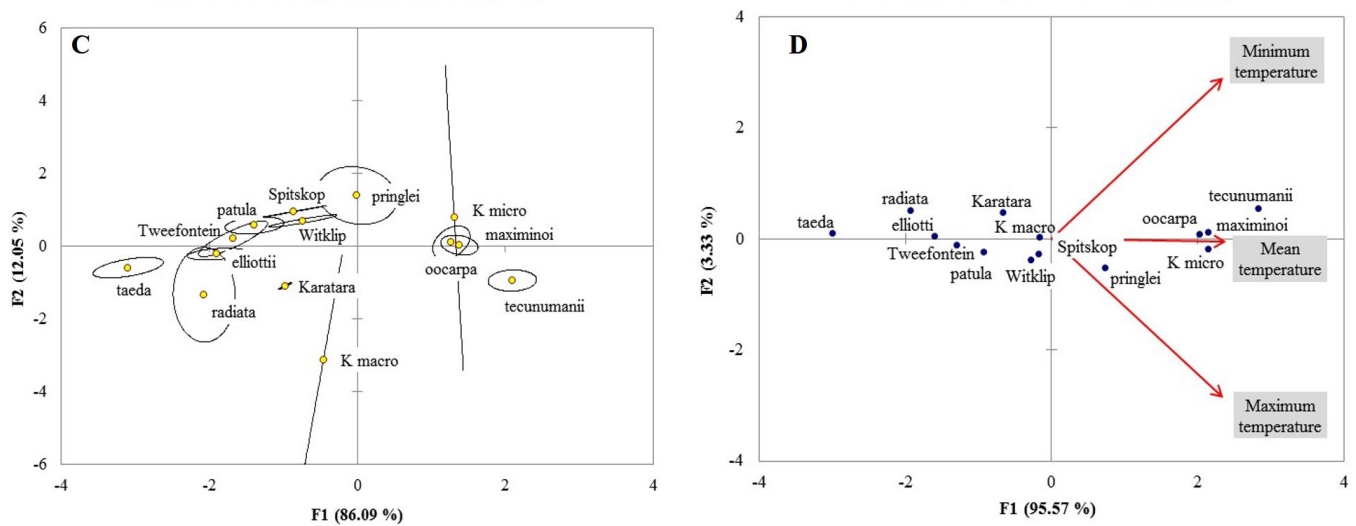

Figure 6 Comparison of environmental conditions between the eight Pinus species Karatara, Spitskop Tweefontein and Witklip with biplots (A - DA and B - PCA) for all five variables (altitude, precipitation and temperature (maximum, minimum and mean)) and only temperature-related variables (C - DA and D - PCA).

are more dependent on them than temperature alone (Young et al. 1993).

However, if altitude is left out of the equation, not only was patula grouped with taeda, radiata and elliottii; but Sabie and Karatara now correlates well (Figure 6C). Maximinoi, oocarpa and tecunumanii remained a separate group from radiata, although Kmic was now more closely related to the trio than Kmax. Length of vectors in the PCA biplot (Figure $6 \mathrm{D})$ indicated that minimum and maximum temperature are more important than mean temperature (Young et al. 1993) for radiata, patuala, elliottii and taeda. Pringlei, te- cunumanii, maximinoi and oocarpa were more closely correlated with the mean temperature which might indicate fewer fluctuations between minimum and maximum temperatures as experienced in Sabie. Although the temperature biplots also indicated that patula and pringlei are grouped closely with radiata, previous crossability attempts yielded low seed viability between these species (Dungey et al. 2003), indicating that mean temperature might not be the only determining factor of hybridisation success. Studies in both tomatoes and herbs indicated that the lower night temperatures, and 24-hour fluctuations between max- 
imum and minimum temperatures, may have a more significant influence on pollen germination and tube elongation than higher average temperatures alone (Peet \& Bartholemew 1996, He et al. 2006).

Although the pollen studies (tube length, width, growth rate length and width) at two temperature regimes (constant for a 7-day period) showed differences between species, it was not conclusive and supportive of the DA and PCA results as indicated above. Pollen studies grouped radiata and tecunumanii together which differed significantly from elliottii and taeda. This again highlights that mean temperature might not be the main determining factor in interspecific hybridisation success, but the temperature fluctuations between minimum and maximum (24-hour) might be more important as observed in herbs and tomatoes.

\section{Conclusions}

Pollination bags placed in the top northern side of trees resulted in not only a lower $\mathrm{RH}$, but a higher temperature and DP. Although the pollination bag placements can decrease the climatic gap in temperatures between Karatara and Sabie for the duration of the pollination season, circadian models indicated that Sabie had a more stable (fewer fluctuations) climate than Karatara. PCA and DA biplots confirmed that the climate of Karatara and Sabie are different and a six-week period climate compensation by virtue of pollen bag placement might not be enough. Elliottii and taeda were also grouped with radiata and Karatara in both sets of PCA and DA biplot analyses. PCA and DA biplots (temperature only) confirmed that minimum temperature is more important to radiata than mean temperature. However, if altitude is ignored as a vector, it might create superficial evidence suggesting patula as a potential hybrid partner for radiata. Future studies should thus investigate elliottii and taeda as potential hybrid partners with radiata. Due to logistic constraints, only the effect of temperature on pollen tube elongation was investigated during the in vitro study. There is also a need for more detailed in vitro pollen studies to investigate the effect of the circadian climate patterns on pollination success. These studies will be reported on in future papers and will address the comparison of the temperature circadian models developed during this study, under in vitro conditions.

\section{Acknowledgements}

Funding for this project was made available through grants from the National Research Foundation (TP 1207122 754), Department of Agriculture, Forestry and Fisheries; MTO Forests; and Camcore. We would also like to thank the MTO Forests and KLF research teams for technical support; Mardé Booysen for assistance with the statistical analyses; and Bill Dvorak for editorial assistance.

\section{References}

Alzoti P.G., Kilimis K., Gallios P., 2010. Temporal and spatial variation of flowering among Pinus nigra Arn. Clones under changing climatic conditions. Forest Ecology and Management 259: 786-797. DOI: 10.1016/j.foreco.2009.06.029

Bannister M.H., 1958. Evidence of hybridization between Pinus attenuata and P. radiata in New Zealand. In Transactions of the Royal Society of New Zealand (85 (2): 217-227). The Society.

Barnes R.D., Mullin L.J., 1978. Three-year height performance of Pinus elliottii Engelm. var. elliottii x P. taeda L. hybrid families on three sites in Rhodesia. Silvae Genetica 27: 217-223.

Bester C., van der Merwe L.H.C., Malema JL., 2000. Controlled pollination in Pinus patula: constraints and possible solutions. South Africa Forestry Journal 198: 109-112. DOI: $10.1080 / 10295925.2000 .9631285$

Bioclim, 2016. Historical weather data. WorldClim Global Climatic Data. Web: http://www.worldclim.org/ bioclim. Accessed 1 October 2016.

Boyer W.D., 1981. Longleaf pine cone production related to pollen density. In: Kraus J. (ed.), Seed yield from southern Pine seed orchards. Georgia Forest Research Council, Macon, GA, USA, pp 8-14. 
Bramlett D.L., O’Gwynn C.H., 1981. Controlled Pollination. In: Franklin E.C. (ed.), Pollen management handbook. Agriculture Handbook Number 587, United States Department of Agriculture, Washington, pp 4457.

Burdon R.D., 1977. Photoperiodic effect on pollen shedding in Pinus radiata? New Zealand Journal of Forest Science 7: 214-215.

Chira E., Berta F., 1965. Eine der ursachen der nichtkreuzungsfähigkeit von arten aus der gattung Pinus [One of the causes of non-crossing ability of species in the genus of Pinus]. Biològia (Bratislava) 20: 600-609.

Cook S.A., Stanley R.G., 1960. Tetrazolium chloride as an indicator of Pine pollen germinability. Silvae Genetica 9: 134-136.

Critchfield W.B., 1975. Interspecific hybridization in Pinus: a summary review. In: Fowler DP, Yeatman C.Y. (eds.), Proceedings of symposium on interspecific and interprovenance hybridization in forest trees. Canada Tree Improvement Association Part II, pp. 99-105.

Cappa E.P., Marcó M., Nikles D.G., Last I.S., 2013. Performance of Pinus elliottii, Pinus caribaeae, their F1, F2 and backcross hybrids and Pinus taeda to 10 years in the Mesopotamia region, Argentina. New Forests 44(2): 197-218. DOI: 10.1007/s11056-012-9311-2

Dickson R.L., 1995. Seed production in Pinus radiata D. Don: Impact of climate and site on numbers of emergent female strobili. Ph.D. Dissertation, University of Canterbury, New Zealand.

Dungey H.S., 2001. Pine hybrids - a review of their use, performance and genetics. Forest Ecology and Management 148: 243-258. DOI: 10.1016/S03781127(00)00539-9

Dungey H.S., Carson M.J., Low C.B., King N.G., 2003. Potential and niches for inter-specific hybrids with $\mathrm{Pi}$ nus radiata in New Zealand. New Zealand Journal of Forest Science 33: 295-318.

Dvorak W.S., Jordon A.P., Hodge G.P., Romero J.L., 2000. Assessing evolutionary relationships of pines in the Oocarpae and Australes subsections using RAPD markers. New Forests 20: 163-192. DOI: 10.1023/A:1006763120982

Dvorak W.S., Potter K.M., Hipkins V.D., Hodge G.R., 2009. Genetic diversity and gene exchange in Pinus oocarpa, a Mesoamerican pine with resistance to the pitch canker fungus (Fusarium circinatum). International Journal of Plant Science 170: 609-626. DOI: 10.1086/597780

Dvorak W.S., 1985. One-year provenance/progeny results of Pinus tecunumanii from Guatemala established in Brazil and Colombia. Commonwealth Forest Review 64: 57-65.

El-Kassaby Y.A., Reynolds S., 1990. Reproductive phenology, parental balance, and supplemental mass pollination in a Sitka-spruce seed-orchard. Forest Ecology and Management 31: 45-54. DOI: 10.1016/0378-1127(90)90110-W

Ellstrand N.C., 2014. Is gene flow the most important evo- lutionary force in plants? America Journal of Botany 101(5): 737-753. DOI: 10.3732/ajb.1400024

Erasmus S.W., Muller M., van der Rijst M., Hoffman L.C., 2016. Stable isotope ratio analysis: A potential analytical tool for the authentication of South African lamb meat. Food Chemistry 192: 997-1005. DOI: 10.1016/j. foodchem.2015.07.121

Fernando D.D., Lazarro M.D., Owens J.N., 2005. Growth and development of conifer pollen tubes. Sexual Plant Reproduction 18: 149-162. DOI: 10.1007/s00497-0050008-y

Ferrand J.C.H., 1988. Electric heating units in pollination bags avoid damage to flowers by spring frost. Annales des Sciences Forestieres 45:157-160. DOI: 10.1051/ forest: 19880205

Gernandt D.S., Lopez G.G., Garcia S.O., Liston A., 2005. Phylogeny and classification of Pinus. Taxon 54: 29-42. DOI: $10.2307 / 25065300$

Greenwood M.S., Schmidtling R.C., 1981. Regulation of catkin production. In: Franklin E.C. (ed.), Pollen management handbook. USDA and Southern Forest Tree Improvement Committee, Agriculture Handbook nr. 587, pp 20-25.

Gruwez R., De Frenne P., De Schrijver A., Leroux O., Vangansbeke P., Verheyen K. 2014. Negative effects of temperature and atmospheric depositions on the seed viability of common juniper (Juniperus communis). Annales of botany - London 113: 489-500. DOI: 10.1093/ aob/met 272

Hagedorn S.F., Raubenheimer G.L., Nel A., 1997. Test results of a pollination bag trial and a pollen viability study for Pinus patula. ICFR Bulletin: 10/1997.

Hagedorn S.F., Raubenheimer G.L., 1996. Flowering and pollination studies of Pinus patula: first results. ICFR Bulletin: 04/1996.

Hagedorn S.F., 2000. The effect of pollination bags on cone survival and seed set in Pinus patula. ICFR Bulletin: 13/2000.

He Y.P., Duan Y.W., Liu J.Q., Smith W.K., 2005. Floral closure in response to temperature and pollination in Gentiana straminea Maxim. (Gentianaceae), an alpine perennial in the Qinghai-Tibetan Plateau. Plant Systematics and Evolution 256: 17-33. DOI: 10.1007/ s00606-005-0345-1

Huyn S.K., 1976. Interspecific hybridization in pines with the special reference to Pinus rigida $\mathrm{x}$ taeda. Silvae Genetica 25:188-191.

Jett J.B., Frampton J.L., 1990. Effect of rehydration on in vitro germination of loblolly pine pollen. Southern Journal of Applied Forestry 14: 48-51.

Kanzler A., Nel A., Ford C., 2014. Development and commercialisation of the Pinus patula x P. tecunumanii hybrid in response to the threat of Fusarium circinatum. New Forests 45(3): 417-437. DOI: $10.1007 / \mathrm{s} 11056-$ 014-9412-1

Kohler U., Luniak M., 2005. Data inspection using biplots. Stata Journal 5: 208-223.

Krugman S.L., Jenkinson J.L., 1974. Pinus L. Pine. In: 
Schopmeyer C.S. (ed.), Seeds of woody plants in the United States. US Department of Agriculture, Agriculture Handbook 450, Washington DC, USA, pp 598-638.

Lu P., Derbowka D., 2012. Effects of seedling age on blister rust resistance assessments in eastern white pine and its hybrid backcrosses. Canadian Journal of Forest Research 42: 67-74. DOI: 10.1139/x11-164

Major J.E., Mosseler A., Johnsen K.H., Rajora O.P., Barsi D.C., Kim K-H., Park J-M., Campbell M. 2005. Reproductive barriers and hybridity in two spruces, Picea rubens and Picea mariana, sympatric in eastern North America. Canadian Journal of Botany 83: 163-175. DOI: $10.1139 / \mathrm{b} 04-161$

McWilliam J.R., 1959a. Interspecific incompatibility in Pinus. America Journal of Botany 46: 425-433. DOI: $10.2307 / 2439138$

McWilliam J.R., 1959b. Effect of temperature on pollen germination of Pinus and its bearing on controlled pollination. Forest Science 5: 10-17.

Neal P.R., Anderson G.J., 2004. Does the 'old bag' make a good 'wind bag'?: comparison of four fabrics commonly used as exclusion bags in studies of pollination and reproductive biology. Annals of Botany 93:603-607. DOI: $10.1093 / \mathrm{aob} / \mathrm{mch} 068$

Nel A., van Staden J., 2005. Pollen morphological features of temperature on pollen germination of various Pinus species. South African Journal of Botany 71: 88-94. DOI: 10.1016/S0254-6299(15)30154-X

Ott R.L., Longnecker M., 2001. An introduction to statistical methods and data analysis. $5^{\text {th }}$ Edition Belmont, California: Duxbury Press, USA.

Owens J.N., Bennet J., L'Hirondelle., 2005. Pollination and cone morphology affect cone and seed production in lodgepole pine seed orchards. Canadian Journal of Forest Research 35: 383-400. DOI: 10.1139/x04-176

Owens J.N., Fernando D.D., 2007. Pollination and seed production in western white pine. Canadian Journal of Forest Research 37: 260-274. DOI: 10.1139/x06-220

Peet M.M., Bartholemew M., 1996. Effect of night temperature on pollen characteristics, growth, and fruit set in tomato. Journal of the American Society for Horticultural Science 121: 514-519.

Plomion C., Chagné D., Pot D., Kumar S., Wilcox P.L., Burdon R.D., Prat D., Peterson D.G., Paiva J., Chaumeil P., Vendramin G.G,. Sebastiani F., Nelson C.D.,
Echt C.S., Savolainen O., Kubisiak T.L., Cervera M.T., de Marìa N., Islam-Faridi M.N., 2007. Pines. In: Kole C. (ed.), Genome mapping and molecular breeding in plants, forest trees (volume 7). Springer, pp 29-92. DOI: 10.1007/978-3-540-34541-1_2

Poynton R.J., 1979. Tree Planting in Southern Africa, Vol. 1. The Pines. Pretoria: Department of Forestry. pp. 882.

Rencher A.C., 2002. Methods of Multivariate Analysis. 2nd ed. John Wiley, New York. DOI: 10.1002/0471271357

SAS Institute., 2013. SAS Version 9.2. SAS Institute Inc, SAS Campus Drive, Cary, North Carolina 27513.

Shapiro S.S., Wilk M.B., 1965. An analysis of variance test for normality (complete samples). Biometrika 52: 591-611. DOI: 10.1093/biomet/52.3-4.591

Sweet G.B., Dickson R.L., Donaldson B.D., Litchwark H., 1992. Controlled pollination without Isolation - a new approach to the management of radiata pine seed orchards. Silvae Genetica 41: 95-99.

Taylor L.P., Hepler P.K., 1997. Pollen germination and tube growth. Annual Review of Plant Physiology and Molecular Biology 48: 461-491. DOI: 10.1146/annurev. arplant.48.1.461

Theron K., 2000. Site requirements and species matching. In: Owen D.L. (ed.), South African Forestry Handbook. SAIF: Pretoria, South Africa, pp 32-44.

Van der Sijde H.A., Roelofsen J.W., 1986. The potential of pine hybrids in South Africa. South Africa Forestry Journal, March: 5-14.

Williams C.G., 2009. Conifer reproductive biology. Springer. pp 168. DOI: 10.1007/978-1-4020-9602-0

Williams J.H., 2012. Pollen tube growth rates and the diversification of flowering plant reproductive cycles. International Journal of Plant Science 173: 649-661. DOI: $10.1086 / 665822$

Wright J.A., Shaw M.P.J., Hadebe W., 1991. Genotype x environment interaction in pine hybrid families at four sites in South Africa. Forest Ecology and Management 40: 93-99. DOI: 10.1016/0378-1127(91)90095-D

Young F.W., Faldowski R.A., McFarlane M.M., 1993. Handbook of statistics. Elsevier Science, Amsterdam, Netherlands.

Zobel B., Talbert J., 1984. Applied forest tree improvement. The Blackburn Press, Caldwell, New Jersey, USA. pp 505. 